\title{
Sikret Fren: economic costs and moral values in a friendship ritual in Honiara, Solomon Islands
}

Sikret Fren : coûts économiques et valeurs morales dans un rituel d'amitiés à Honiara, îles Salomon

\section{Rodolfo Maggio}

\section{(2) OpenEdition}

\section{Journals}

Electronic version

URL: http://journals.openedition.org/jso/7796

DOI: $10.4000 /$ jso. 7796

ISSN: $1760-7256$

\section{Publisher}

Société des océanistes

\section{Printed version}

Date of publication: 15 December 2017

Number of pages: 77-90

ISSN: 0300-953x

\section{Electronic reference}

Rodolfo Maggio, "Sikret Fren: economic costs and moral values in a friendship ritual in Honiara, Solomon Islands", Journal de la Société des Océanistes [Online], 144-145 | 2017, Online since 15 December 2019, connection on 15 March 2021. URL: http://journals.openedition.org/jso/7796 ; DOI: https://doi.org/10.4000/jso.7796

\section{(c) (†) $\odot$}

Journal de la société des océanistes est mis à disposition selon les termes de la Licence Creative Commons Attribution - Pas d'Utilisation Commerciale - Pas de Modification 4.0 International. 


\section{Sikret Fren: economic costs and moral values in a friendship ritual in Honiara, Solomon Islands}

Sikret Fren : coûts économiques et valeurs morales dans un rituel d'amitié à Honiara, îles Salomon

\section{Rodolfo Maggio}

\section{(2) OpenEdition}

\section{Journals}

Electronic version

URL: http://journals.openedition.org/jso/7796

DOI: $10.4000 /$ jso.7796

ISSN: $1760-7256$

Publisher

Société des océanistes

Printed version

Date of publication: 15 December 2017

Number of pages: $77-90$

ISSN: 0300-953x

Electronic distribution by Cairn

\section{CAIRN}

CHERCHER, REPÉRER, AVANCER

\section{Electronic reference}

Rodolfo Maggio, «Sikret Fren: economic costs and moral values in a friendship ritual in Honiara, Solomon Islands », Le Journal de la Société des Océanistes [Online], 144-145 | 2017, Online since 15 December 2019, connection on 22 December 2017. URL : http://journals.openedition.org/jso/7796 ; DOI : $10.4000 /$ jso. 7796 


\section{Sikret Fren: economic costs and moral values in a friendship ritual in Honiara, Solomon Islands}

by

Rodolfo MAGGIO*

\begin{abstract}
This article analyses the case of Sikret Fren, a like-forlike gift exchange ritual organised by the members of the Anglican church of Gilbert Camp, an illegal settlement on the outskirts of Honiara, Solomon Islands. The objects exchanged, the people involved, and their relationships are discussed according to Gregory's analytical opposition between Gift and Commodity. The resulting categorization of people, objects, and relationships is looked at from the perspective of the Domestic Moral Economy developed by Peterson \& Taylor. The article locates Sikret Fren in relation to the cultural, historical, geographical, and socio-economic context in which it was developed; illustrates the rationale behind the reciprocal transactions of identical gifts between ritual friends; and suggests that urban and peri-urban settlers use their cultural creativity in reaction to the moral and economic challenges caused by the incompatibilities between their values and their material conditions.
\end{abstract}

KeYwords: ritual, gifts and commodities, domestic moral economy, urban settlements, Solomon Islands, Honiara

In 2011-2012 I conducted 13 months of fieldwork in Gilbert Camp, a settlement situated on the outskirts of Honiara, capital city of Solomon Islands (Maps 1 and 2). ${ }^{1}$ The aim of my research was to examine the domestic moral economy (Peterson and Taylor, 2003) of the settlers. The term "moral economy" was first used to refer to morally acceptable economic relationships between people

\section{RÉSUMÉ}

Cet article analyse l'échange de cadeaux à lidentique appelé Sikret fren qui est pratiquée par les membres de l'Eglise anglicane de Gilbert Camp, un quartier de squatters situé en périphérie d'Honiara, aux îles Salomon. Au moyen de l'analyse de Gregory sur la distinction entre dons et marchandises, jexamine les objets échangés, les gens impliqués dans cet échange et les relations qui les lient. J'analyse ensuite la catégorisation des gens, des objets et des relations quils entretiennent à partir de l'approche sur l'économie morale domestique développée par Peterson \& Taylor. Cet article situe Sikret fren dans les contextes culturels, historiques, géographiques et socioéconomiques qui lui ont servi de creuset. Il illustre la logique qui soustend l'échange de cadeaux identiques entre amis rituels et suggère que les résidents des quartiers informels urbains et périurbains font preuve de créativité en réagissant aux défis moraux et économiques causés par les incompatibilités entre leur système de valeurs et leurs conditions matérielles de vie.

Mots-CLÉs : rituel, dons et marchandises, économie morale domestique, quartiers informels urbains, îles Salomon, Honiara

(Blizard, 1796; Bell, 1807). In the work of the social historian E.P. Thompson (1971), the term was later used to explain the $18^{\text {th }}$ century English food riots. At the time, buying cheaper and selling dearer was strongly condemned, and even forbidden by the English common law. Thompson argued that that was the time when the market economy of commerce progressively triumphed on the moral

1. The country's name, as established in the Constitution of Solomon Islands, is "Solomon Islands", with no definite article.

* Postdoctoral Researcher, University of Oxford, Rodolfo.maggio@psych.ox.ac.uk 


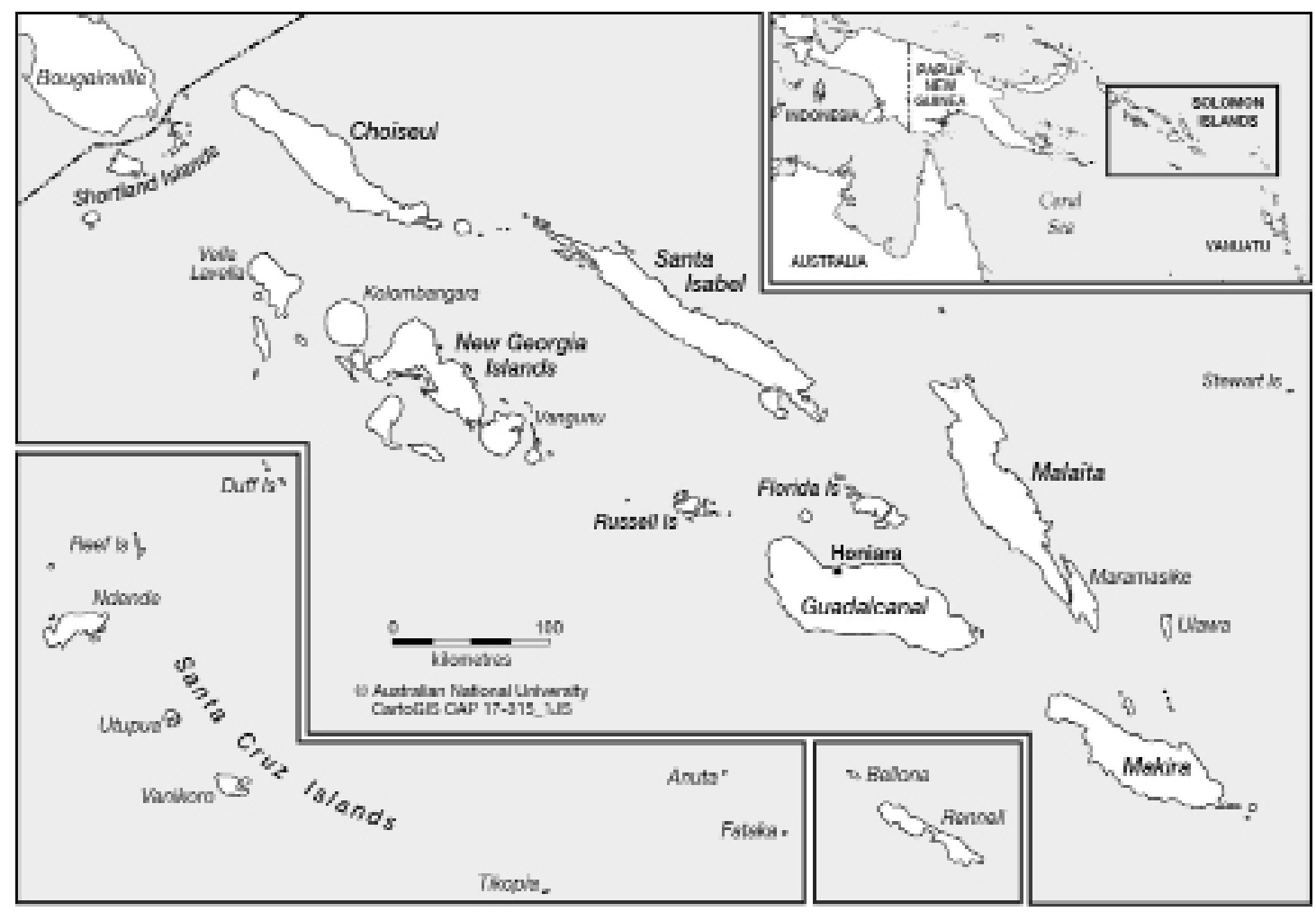

MAP 1. - Archipelago of Solomon Islands (@ Australian National University CartoGIS CAP 17-315-1JS)

economy of provision. Nevertheless, he admits, people maintained traditional economic practices and ideas about what is a 'good' way of producing, exchanging, distributing and consuming. The expression entered the anthropological literature with the book by James Scott, The Moral Economy of the Peasant: Rebellion and Subsistence in Southeast Asia (1976). Since then, it has become popular in the discipline and Peterson and Taylor (2003) used it in their work on Indigenous Australia. They added the adjective 'domestic' in order to explore the impact of economic changes in indigenous Australia. In their model, sharing with kin is given a central place and is heuristically actualized in order to appreciate the systematic intertwining of an ethic of generosity that is socially concretised in acts of giving. Inscribed into a flow of goods and services, these acts produce and reproduce social relationships. As a product of these usages in political economy and anthropology, the concept of domestic moral economy currently refers to the concrete interpenetration of the economy within the morality of a group of people who construct each other as kin-related. Here I explore their negotiation of moral and economic values through the analysis of a ritual called in pidgin Sikret Fren ("Secret Friend"). During this ritual, thirty-six women exchanged thirty-six gifts, equal in kind and monetary value, in a total of eighteen exchanges.
"What is the point of exchanging $\$ 160 \mathrm{SBD}^{2}$ of cups for $\$ 160$ sBD of cups?"

I asked myself as I was recording those reciprocal transactions. I inquired, and observed that it was possible to explore the logic of Sikret Fren by looking at how Solomon Islanders negotiate their economic and moral priorities in their everyday lives. I also looked at how they confront dilemmas emerging from concrete incompatibilities between the importance of being 'good' community members and the need to make ends meet. I thus realised that Sikret Fren is an expression of the cultural creativity with which Solomon Islanders cope with their multiple economic liabilities and moral commitments.

In order to present my argument, I begin with a introduction to my field site from the historical, geographical, and demographic point of view. Then, I make use of a page of my field diary to provide a description of the ritual. On the basis of this sketch, I explain the salient features of Sikret Fren as well as the relationship between the people involved. The rest of the chapter is devoted to the discussion of this ritual as a space of negotiation between moral and economic values. I explore such negotiation in comparison with other exchanges of like-for-like gifts in Melanesia, and discuss their differences and similarities through the lens of the theoretical framework conceptualised by Chris

2. $\mathrm{SBD}$, or Solomon Islands Dollars, is the national currency of Solomon Islands. Currently, $£ 1=\$ 11.60$ SBD. 


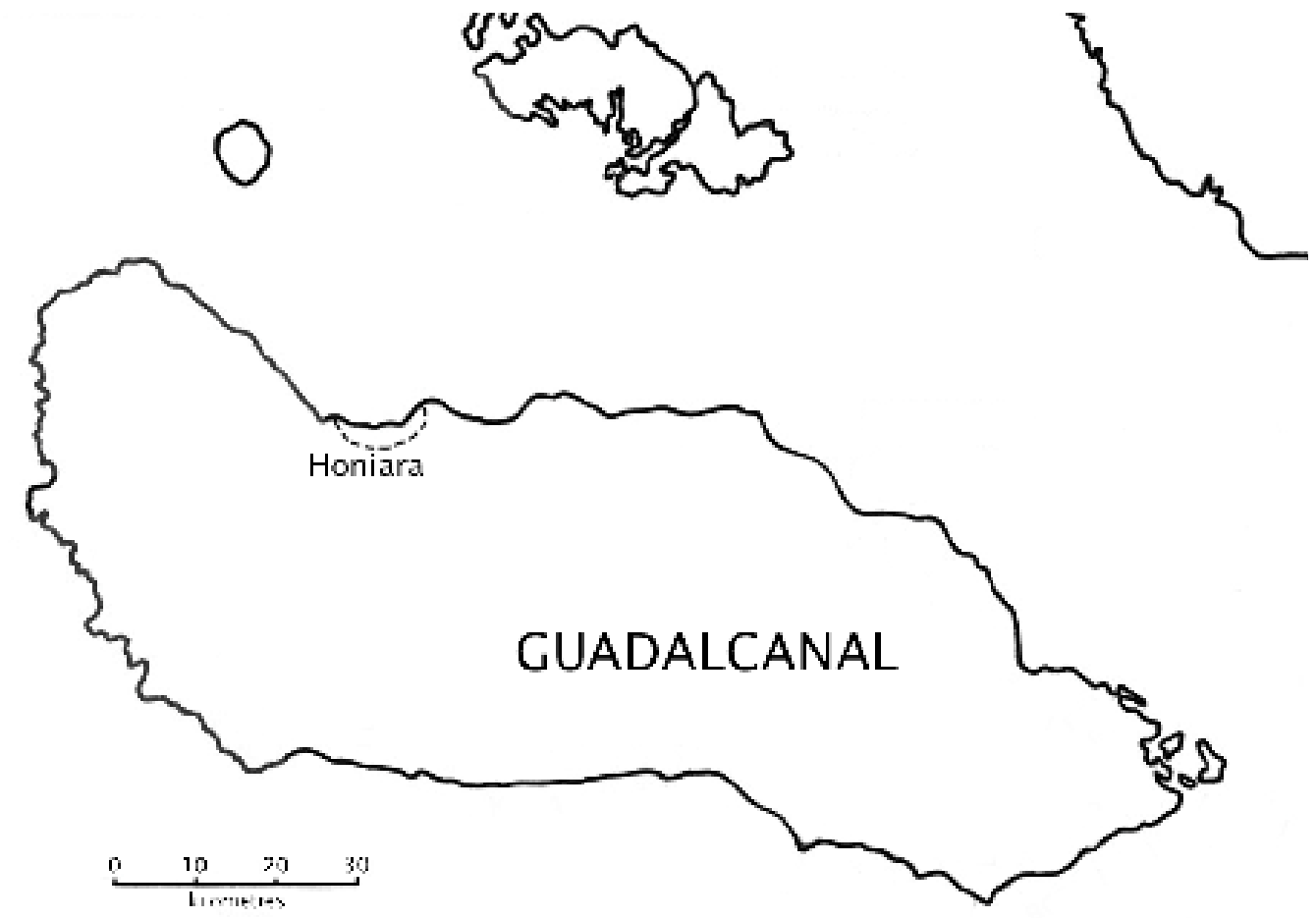

MAP 2. - Guadalcanal and Honiara

Gregory in Gifts and Commodities (1982). More specifically, I compare features like equality/inequality, alien/non-alien, and debt/credit in order to situate Sikret Fren on the gift-commodity continuum. Both the ethnographic description and the subsequent theoretical analysis are presented within a narrative framework that I conceptualized as the "storytelling of anthropology", which accounts simultaneously for intellectual reflexivity and engaged anthropological analysis (Maggio, 2014; Maggio \& Symons, 2014). My argument is that the settlers developed this ritual as a way to effectively resolve the dilemma between the moral obligations of a gift society and the limited resources circulating in the contracting economy of a Melanesian capital. More specifically, I claim that the settlers managed to do so by socially constructing exchange objects that are at once gifts and commodities, thereby using their domestic moral economy to define their legitimacy and necessity.

Gilbert Camp (Maps 3 and 4) is one of the "squatter" settlements that have been mushrooming in and around Honiara since the end of WwII, when the town, previously an American military base, was proclaimed capital city of Solomon Islands. It is situated across the south-easternmost segment of the town boundary. About a quarter of the settlement lies within the area administered by the Honiara City Council, on land that was alienated to the indigenous tribes of Haubata and
Kakau. The other three quarters lie on an area classified as Customary Land, and administered by the Guadalcanal Provincial Government.

In Gilbert Camp, approximately 3,084 individuals (including children) currently inhabit about 468 households (rented houses included). On average, 6 to 7 people live in an ordinary household, although I found houses where only one person was living and houses inhabited by a family of 24. Usually, between 3 and 4 children live in each household, although few houses have no children and some up to 17 children. It is very common in any household to have at least 1 to 2 relatives with a one-degree of kinship distance, but I found households where this number reaches 15 . Indeed, less immediate relatives commonly move to Honiara in order to attend a form of education that might not be available in the provinces, or to find a job.

Gilbert Camp is largely a Malaitan settlement. My ethno-linguistic survey reveals that $80 \%$ of its population was born in Malaita province or has a Malaitan background. People from other provinces, especially Makira-Ulawa and Western Province, make up the remaining 20\% along with a few migrants from Papua New Guinea. Among the people sharing Malaitan origins, most identify with the Kwaraae ethno-linguistic category $(72 \%)$, the largest in Solomon Islands. ${ }^{3}$ In Gilbert Camp, about $80 \%$ of the settlers cultivate a horticultural garden, which provides 


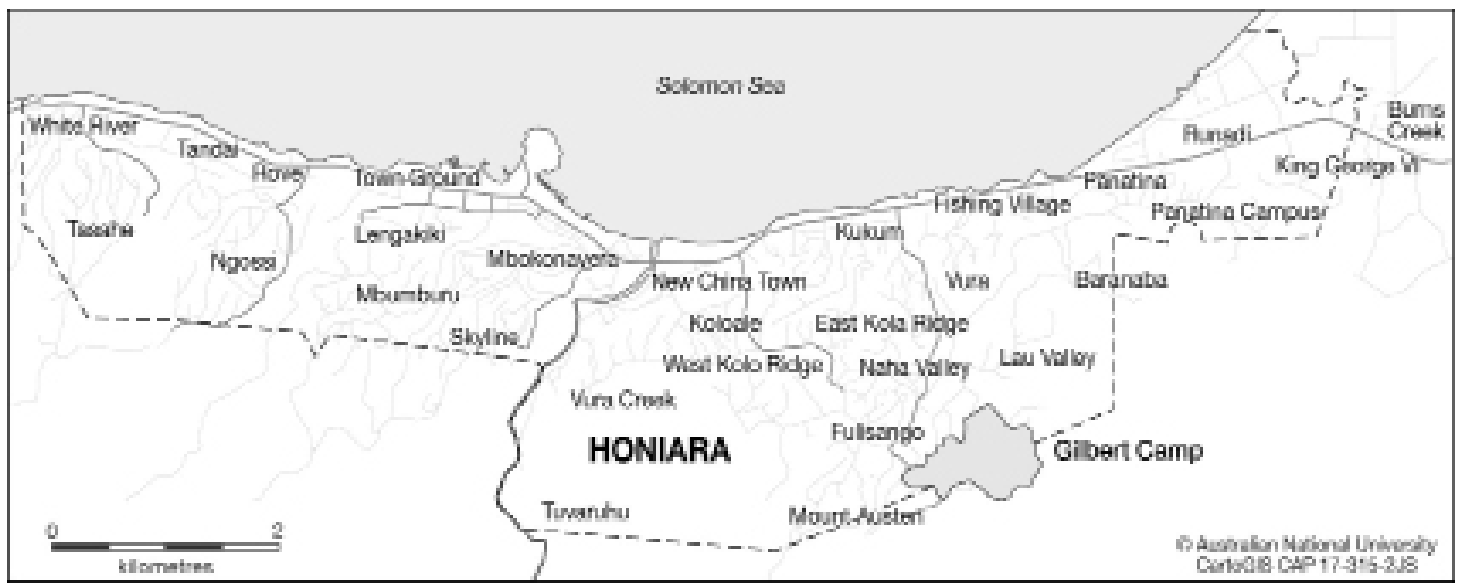

MaP 3. - Gilbert Camp and the Honiara Town Boundary (C) Australian National University, CartoGIS CAP $17-315-2 J S)$

tubers, such as cassava and the less common sweet potato, and greens, including slippery cabbage, sweet fern and snake beans. To make money, settlers have a paid job in town and/or engage in many sorts of income-generating activities, ranging from selling the produce of their gardens, to baking cakes, to printing labels on t-shirts.

The average income that the members of one typical household manage to generate is SBD \$1225 fortnight (around £108). Considering that 3 adults and 4 children live in an average household, it follows that each person has about one pound a day to survive.

These brief notes serve the purpose of contextualizing the following case study, which, although being relevant for the whole population, concentrates on a fraction of it: women of the Mothers Union of the Anglican Church of Gilbert Camp who took part in an end-of-the-year ritual known as Sikret Fren.

\section{The ritual}

\section{"Saturday, November $12^{\text {th }}$}

"Around eight in the evening, about a hundred people gathered in the courtyard of the Christ The King church, the Anglican church of Gilbert Camp. [...] I observed three main social happenings: a succession of dances, a sequence of choral songs, and a series of gift exchanges. These three events were interspersed with speeches by the chaplain, the leader of the Mothers Union, plus some jokes and pantomimes. [...] Today, Gordon asked me if I could take pictures of the event. I was happy to do that [...] So, during the ritual, I was taking pictures but without asking myself too many questions about what was going on in front of my camera. I did so until I noticed something that I found peculiar.

"Thirty-six women, all members of the Mothers Union, exchanged gifts during eighteen exchanges. Each pair of exchangers performed the exchange wit- hin a circle formed by spectators, other women waiting to exchange or who had already exchanged, and some of the church staff. The pairs met at the centre of the circle; the two women presented their gifts in turn, and also exchanged some women's clothes. [...]

"At the beginning, everything looked normal to me somehow. But then I noticed what the women were donating to each other. I saw Delilah giving a set of dishes and cups to Madeleine, and Madeleine reciprocating with a set of dishes and cups too. They were the same type of dishes, the same cups, and they were equal in quantity. 'Why are they exchanging equal amounts of the same things?' I asked myself. 'Maybe Delilah and Madeleine have accidentally bought the same gift?' I thought. This would close the question, were it not for the fact that also Wendy and Ethel each donated to the other the same amount of cups and plates. At that point I started to feel the suspicion that this was not by chance.

"That night, all the participants were enjoying the feast very much. I did not want to bother anyone with the many questions that were popping in my head after what I saw. I was sure, though, that it was not the case that they were exchanging things in equal amounts by chance. 'If it was not the case' I thought, 'then I might have a case!'." (Excerpt from field diary)

\section{What is Sikret Fren? Morality}

The day after, I started to visit some of the women who had taken part in the ritual exchange. I asked them questions regarding what happened in the churchyard, what they were doing, why, why with a particular exchange partner rather than another. They told me that what they were doing was called Sikret Fren, a ritual exchange celebrated since six or seven years in the Anglican church of Gilbert Camp towards the end of the solar year. Exchange partners referred to each other as "my best friend", and other terms denoting a strong, almost kinship-like, bond. The ritual consisted of an exchange of goods on 


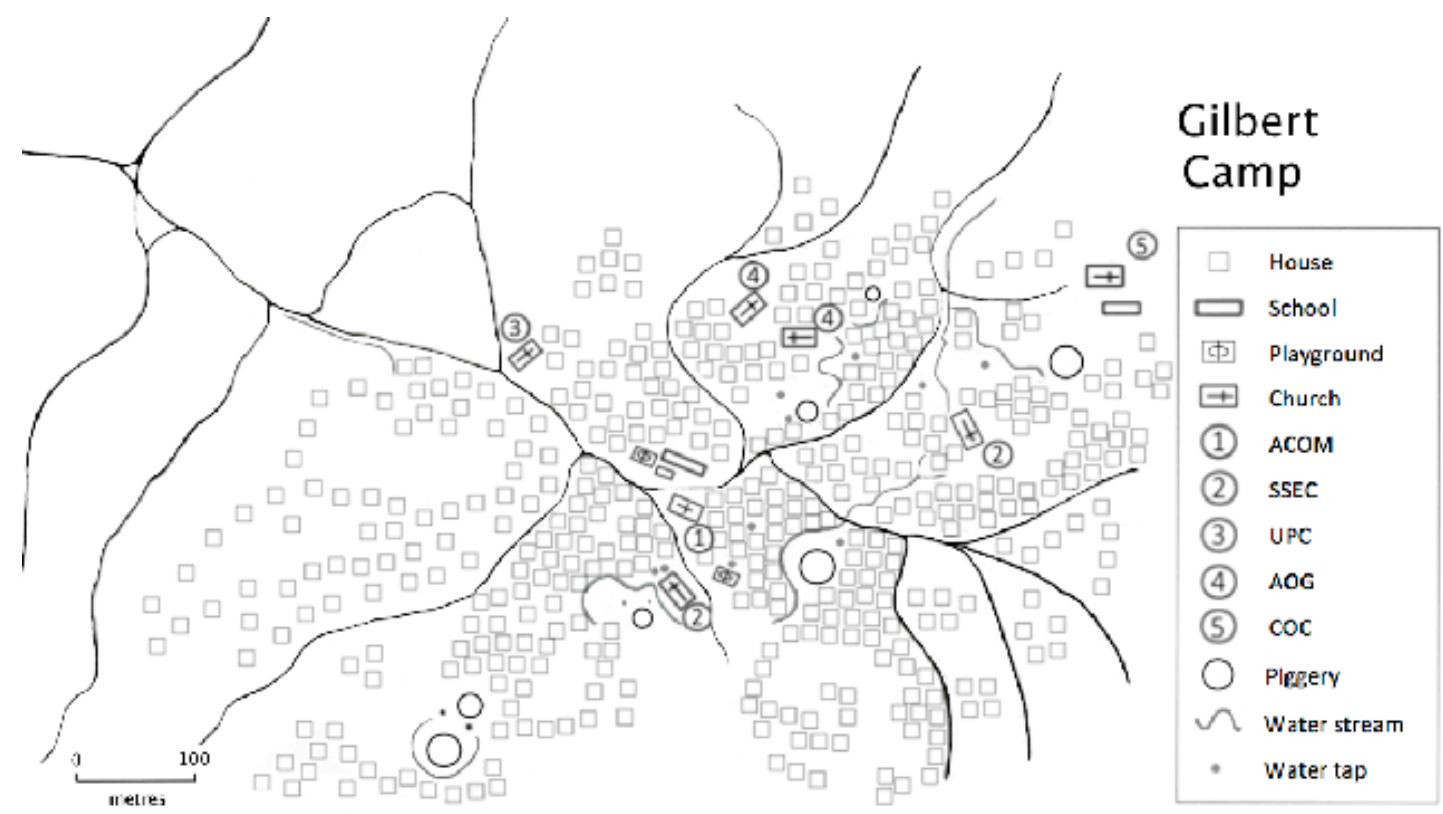

Map 4 - Gilbert Camp

the quality and quantity of which the exchange partners had previously agreed. But, I thought, if the gift is known before the exchange takes place, and the exchange partners also know each other, then what was the Solomon Islands Pidgin term sikret referring to? Is the friend who is secret, the gift, or what?

My interviewees all said that it was the gift that was sikret, not the friend. However, when I asked them, reversing the question, if the gift was secret, they would reply: "Not really". I understood that there was no point in insisting on a contradiction that was occurring only as long as I looked at secret and sikret from my own point of view. Thus, I recorded their replies, and continued on other aspects.

I found out that the agreement between exchange partners was based upon two premises: (1) the economic value of the objects had to be identical; and (2) the gift was to respond to the wishes expressed by the recipient. The exchangers met up before the beginning of the ritual and agreed on the amount of money they were going to spend, as well as what they were going to buy. However, I eventually found out that not all women exchanged identical objects, although most did (Table 1). When I asked those who exchanged different objects why they did so, they simply replied that they needed different things. I also found out that not all women exchanged gifts for the same amount of money, although most did. Precisely, two pairs exchanged gifts of different monetary value: the pair formed by Muriel and Lily (Transaction no. 10), and that formed by Rose and Annette (Transaction no. 11). I want to spend a few more words on these two couples, in order to show how and why their exchanges constitute two exceptions to the rule. As such, their exchanges also provide an explanation of the rule by the very fact of negating it. Indeed, the women in both pairs clearly explained that they did not exchange like-for-like gifts even if they knew that this is what they were supposed to do.

I met Muriel, and, separately, I met Lily. Both laughed when I asked them why they had exchanged gifts of different monetary value. Both said that they did not have the chance to meet before that night on November 12, and that they realised that the quantity and cost of their gifts were unequal only at the time of the exchange. However, they also said that that was not a problem. Muriel, for example, put it this way:

Muriel: She is my kasinsista - lit. female cousin -, we don't need to give the same.

Relatives, she meant, do not have to exchange equal amounts. Later, I met Rose. It was for an interview that was not initially related to the Sikret Fren. I spent a couple of hours with her and her husband, talking about weddings, bride price, and tradition, while sipping some over-sweetened tea. I asked them whether they belonged to any group, political, religious, or otherwise. As I was waiting for the answer, Rose's eyes pointed right, as if that question reminded her of something. So, I asked:

Rodolfo: What were you thinking about?

Rose: I've forgotten to do something important...

Rodolfo: May I ask you what that was?

Rose: I have to go to buy some cups and plates. 


\begin{tabular}{|c|c|c|c|c|c|}
\hline \multirow{2}{*}{ Transaction* } & \multicolumn{2}{|c|}{$\begin{array}{l}\text { Gift from partner A to } \\
\text { partner B }\end{array}$} & \multicolumn{2}{|c|}{$\begin{array}{l}\text { Gift from partner B } \\
\text { to partner A }\end{array}$} & \multirow{2}{*}{$\begin{array}{c}\text { Surplus (+) or } \\
\text { Deficit }(-) \\
\$\end{array}$} \\
\hline & Items & $\$$ & Items & $\$$ & \\
\hline 1 & Plates, cups & 100 & Plates, cups & 100 & 0 \\
\hline 2 & Plates, cups & 100 & Plates, cups & 100 & 0 \\
\hline 3 & Plates, cups & 100 & Plates, cups & 100 & 0 \\
\hline 4 & 3 trays & 100 & 4 trays & 100 & 0 \\
\hline 5 & Plates, cups & 170 & Plates, cups & 170 & 0 \\
\hline 6 & 2 trays & 100 & 3 containers & 100 & 0 \\
\hline 7 & Plates, pots & 120 & Plates, pots & 120 & 0 \\
\hline 8 & 2 cup sets & 200 & 2 cup sets & 200 & 0 \\
\hline 9 & 2 big plates & 200 & Pan, plates & 200 & 0 \\
\hline 10 & Plates, cups & 130 & Plates, cups & 170 & -40 \\
\hline 11 & Plates, cups & 130 & Plates, cups & 100 & +30 \\
\hline 12 & Plates, cups & 86 & Plates, cups & $?$ & $?$ \\
\hline
\end{tabular}

TABLE 1. - Sikret Fren exchanges, Gilbert Camp, November $12^{\text {th }} 2011$

Rodolfo: Do you need cups and plates? It seems to me that there are enough of them here, even for the guests.

Rose: No, it's that during the feast for the closing of the year I had a misunderstanding with my friend, and so she gave me plates and cups for SBD $\$ 130$, and I for only sвD $\$ 100$. So, I have to go and buy something.

Friends, she meant, do have to exchange equal amounts.

In sum, the two cases, that of Muriel and Lily on the one hand, and that of Rose and Annette on the other, not only constitute two exceptions to the rule, but also an explanation for the rule itself. In both cases, indeed, exchange partners exchanged gifts of different monetary values even if they knew they were supposed to give the same. Because the two pairs behaved in a different way from the rest of the group, and because they felt the need to justify such 'transgression', it seems correct to conclude that giving gifts of equal price was a rule that they intended, but failed, to respect.

It is possible to gain a further insight from their subsequent actions. After the ritual took place, Muriel and Lily did not organise another transaction in order to 'balance their accounts', i.e. to make their gifts equal in terms of monetary value. Rose and Annette, in contrast, later met up so that the 'debtor' could give her 'creditor' cups for $\operatorname{SBD} \$ 30$. The reasons given by the two pairs are consistent: friends have to exchange the same, whereas relatives do not have to. In this sense, Sikret Fren should be analysed in relation to the ways in which people differentiate par- ticular relationships. Both pairs were pointing to the fact that friends and relatives are not the same. Relatives, among other things, are people with whom a relation of debt does not generate the need to repay quickly, whereas friends, among other things, are people to whom a debt should be repaid as soon as possible, although this is neither a universal rule, nor a rule that is universally respected. ${ }^{4}$

This distinction is important. Indeed, if the exchange partners differentiate between friends and relatives, and establish a relation between each category and a particular exchange regime, then it is possible to determine a central feature of Sikret Fren, i.e. the kind of relationship created between the exchange partners. If people in Sikret Fren are expected to give each other gifts of equal monetary value, and if they believe that friends have to give each other gifts of equal monetary value, it follows that people who exchange gifts in Sikret Fren look at each other as friends and not as relatives. However, that does not mean that relatives cannot take part, as evidenced by the participation of Muriel and Lily. What matters, within the context of the ritual, is that they look at each other as friends.

But, what did they mean by "friends"? Every woman I spoke with talked about her exchange partner as such. However, it seemed to me that they were using the term fren differently from what they mean by fren in their daily life. As far as debt is concerned, friends and relatives are not really different in this respect. They can pay back, or not, or later. It does not really matter. Debt contracted through gift-giving is a form of

4. Arguably, there is no concrete risk of losing face for those who took part in this ritual. Losing face might be a risk when the exchange partner is a kin. If one has a debt and does not repay it in the long run (possibly exceeding the amount of what was received) he or she can definitely gain a bad reputation. But it is unlikely, for in the long run there is always an opportunity to reciprocate, and the amounts exchanged in Sikret Fren are not disproportionately large compared to the average income of a Gilbert Camp resident. 
connection, not something they necessarily want to get rid of. So, why did Rose want to pay her debt so promptly? Maybe Annette was not a fren for Rose in the same way as a fren would be outside the context of the ritual? Maybe they were "not really" fren? Had they become fren recently? Some of the women I interviewed did not even remember the name of their exchange partner. I suspected that a fren in the context of the ritual was a very different category of person than that of fren outside of the ritual.

I attended the next meeting of the Mothers Union, where I met Betty, the group leader. She answered my questions in a very complete way. She explained that the women had been asked to agree on the price and the nature of the gifts. In short, all things I already knew from observations and interviews. So, I posed her the question: "were the pairs randomly selected?" Betty looked a bit surprised, and replied that, yes, that's how it was. To be precise, eighteen out of thirtysix women wrote their name on eighteen pieces of paper, which they placed in a plastic bag, and the other eighteen extracted one per head. So, not only were the gifts "not really" "secret". Also, the exchange partners were "not really" "friends", which is arguably why everyone - except Muriel and Lily - avoided contracting debt relations so consistently.

\section{What is Sikret Fren for? Economy}

To sum up, besides two exceptions that confirm the rule, Sikret Fren had been performed on the basis of an agreement between exchange partners who chose their reciprocal gifts according to their personal needs and circumstances. However, this conclusion only describes. It does not explain why the ritual as a whole was organised. In other words, what is the point of buying a gift for your exchange partner in order to get what you want in return, when you can just buy what you want straight away and with the same expenditure? In order to answer this question we

need to look at the economy in Gilbert Camp, and at the moral values of its inhabitants.

With less than a pound a day, people in Gilbert Camp do not have enough resources to put food on the table and save money at the same time. Living on the threshold of subsistence, they do not even dream of Christmas gifts or presents for the end of the school. In addition, gifts sometimes have an even more problematic feature: they might occur on dates close to each other, and at times of the year when heavy expenditures already weighs on the household economy.

This is the case of New Year's Eve, Christmas, the end of the high school (December 2), and the end of the Summer School (November 26). Since these celebrations are so close to each other, it would be impossible for people in Gilbert Camp to have enough money to meet the expenditure resulting from the organisation of feasts and the purchase of gifts, and also buy the food they need to survive during that period. Nevertheless, the period ought not to pass without celebrations and related donations, the women of the Mothers Union think. So, they conflated multiple acts of gift-giving into a single public ceremony. That is what Joyce meant when she said that her Sikret Fren was a "Christmas present", even if she gave it to Georgina more than a month before Christmas. In addition, the exchange partners also merged these multiple acts of gift-giving with an ordinary purchase of useful goods. Indeed, as Helen admitted, "we all need cups and plates. It's to drink, and to eat."

So, people in Gilbert Camp think that it is important to behave as 'good' community members who exchange gifts on important occasions. But because gifts cost money, and there is so little 
of it, they cannot spend that money on useless objects. Gifts symbolise friendship and unity, but in conditions of financial hardship they must also be materially beneficial. Sikret Fren, it follows, provides the women of the Mothers Union with an opportunity to publicly demonstrate how highly they value their community, and simultaneously buy the goods they needed. With one single disbursement, they obtained two things: useful goods, and moral recognition. Still, it is not enough to conclude that the ritual was organised in order to obtain at the same time useful goods and moral recognition. Put in this way, this conclusion seems to suggest that economic benefit and moral recognition are given the same value. In contrast, my contention is that, as far as the ritual is concerned, the aim of the exchangers lies much more in their acting as moral agents, rather than in the purchase of useful goods.

What is Sikret Fren for? "Not really" economy As I have already mentioned, the money disbursed to purchase the goods is the same spent to buy the gifts. In terms of monetary expenditure, there is no difference between buying cups and plates at the corner shop and obtaining them as counter-gift. To put it briefly, organising the ritual does not result in any form of economic gain. Thus, all that is added to the purchase (i.e. the gift exchange) and all that is built around the transaction (i.e. the ritual itself) are constructed for aims other than obtaining useful goods. Even though the Mothers organised the ritual in order palliate to the lack of money, they did not do it in order to save money or obtain the objects. Rather, the ritual was organised notwithstanding economic disadvantage. In the absence of any economic benefit, the whole point of Sikret Fren is moral recognition.

But this conclusion does not close the matter. Rather, it opens up the question regarding what kind of morality Sikret Fren is meant to make visible, and thus recognizable. In order to explore this aspect, it is necessary to undertake an analysis of the salient features of the ritual. I attempt to do so on the basis of other ethnographic studies of Melanesian like-for-like exchange. However, in situating my understanding of Sikret Fren in a comparative and theoretical framework, I hope not to lose the specificity of this particular case. Indeed, rather than fitting within one of the abstract categories of exchange that anthropologists have theorised, the features of Sikret Fren, I suspect, place this ritual somewhere at the threshold between opposed exchange regimes, in a sort of grey area where exchange relations and the fundamental traits of the things exchanged escape intellectual essentialisation. The paragraphs below explain this assertion by placing Sikret Fren on the continuum between gifts and commodities, a continuum between forms of reciprocity à la Sahlins (1972) that accounts for variations rather than providing an essentializing definition.

Malinowski inaugurated the study of like-forlike exchanges in Melanesia. With reference to the fact that

"in savage communities, whether bountifully or bad-
ly provided for by nature, everyone has the same free
access to all the necessities" (Malinowski, 1922: 129),

he asked:

"Why make a present of it, if it cannot be returned except in the same form?"

He identified two faulty assumptions in the rationale underlying such a question: (1) that there can only be an exchange as long as there is differential access to resources; and (2) that there has to be some form of rational expectation of material gain. The first is incorrect because it does not consider

"the love of give and take for its own sake; the active enjoyment in possession of wealth, through handing it over."

The second is faulty because there is no material gain in letting yams rot in the storehouse, nor in displaying them as they go bad, unless one considers the psychological pleasure of wealth exhibition to be material. After a few concessions, Malinowski generalised his conclusion, writing:

"in almost all forms of exchange in the Trobriands, there is not even a trace of gain, nor is there any reason for looking at it from the purely utilitarian and economic standpoint." (Malinowski, 1922: 134)

Above, I illustrated why this theoretical perspective shall be endorsed in order to explain the meaning and significance of Sikret Fren. Thus, the only benefit of recalling Malinowski's reasoning here lies in delineating the comparative and theoretical framework in which the following discussion develops.

It seems thus safe to consider as resolved the relationship between the things exchanged. Now, the relationship between the people exchanging can be explored.

\footnotetext{
"Symmetrical exchange of the same thing [in Melanesian societies] takes place between equals in status, and it is at the same time the prime means of achieving prestige, each prestation being a challenge to demonstrate equality." (Forge, 2004: 135)
}

This is possible because prestige and equality, in the long run, create and are created by a swapping domination between equals in sta- 
tus, a relationship that Andrew Strathern defined as "alternating disequilibrium" (Strathern, 1971: 11). I believe that equality is established also between Sikret Fren exchange partners, but for different reasons and within the context of a peculiar type of domestic moral economy. One reason why it was different is that Forge was looking at a delayed form of like-for-like exchange. There, time played a crucial role, because a successful exchange was conditional upon growing a yam equal in length to the one received. In the context of Sikret Fren, instead, the exchange was simultaneous. Secondly, traditional Melanesian like-for-like exchanges were competitive, which was what made it possible to increase the prestige of transactors and to constantly swap positions in the alternating domination. In contrast, Sikret Fren was not competitive at all. Furthermore, the context is also very different from that of a traditional Melanesian society. If that was not already self-evident, a quick look into the economy of Solomon Islands will illustrate such difference. Before doing so, though, I want to spend a few more words to explain why I recalled Forge's approach to Melanesian like-for-like exchange. The reason is that he looked at these exchanges as efforts to maintain equality (Forge, 1972: 527), which is an aspect that, arguably, characterizes Sikret Fren too.

One feature of Sikret Fren that seems to actualise a relation of equality is the tendency, mentioned above, to ignore the name of the exchange partner. Uwe Skoda recognised the same feature in his analysis of ritual friendship in northwest Oris$\mathrm{sa}$, where ritual friends "address each other only according to the type of friendship". He thinks that this "seems to indicate a tendency to equalize and avoid hierarchical connotations" (Skoda, 2004: 167). It appears therefore that the tendency to ignore the name of the exchange partner can be interpreted as denoting a relationship of equality. Name ignorance and referencing exchange partners only as friends, thus, is another feature that coherently fits within an understanding of Sikret Fren as a Melanesian like-for-like gift exchange aimed at establishing ritual equality.

It follows, therefore, that Sikret Fren seems to establish a relationship of equality between both exchange partners and gifts exchanged that reminds that of Melanesian like-for-like exchanges. One question ensues, and it is the last one that this chapter will pose: what is specific about Sikret Fren in relation to the general category of Melanesian like-for-like exchange?

One possible answer is that Sikret Fren belongs to a specific category of Melanesian like-for- like exchanges, i.e. those organised by Christian churches. Churches in the Pacific have been very successful at adapting indigenous customs to suit their own needs (Dundon, 2011; White, 1991: 92-156). Gregory, for example, analysed a form of like-for-like exchange that was organised by a church in Poreporena, Papua New Guinea, with the aim of accumulating capital (Gregory, 1980: 647). Rather than capital accumulation, as we have seen, Sikret Fren is about the realization and display of moral values. Furthermore, rather than being organised by the Anglican Church of Gilbert Camp, Sikret Fren was organised by a subsection of it, i.e. the Mothers Union. Thus, the question shall be properly reformulated: why did the women of the Mothers Union of Gilbert Camp organize a ritualised gift exchange aimed at the realization and display of moral values? In other words, what aspects characterize Sikret Fren as culturally specific, historically specific, and regionally specific vis-à-vis the general category of Melanesian like-for-like exchanges organised by Christian churches? In order to answer this question, it is useful to look at the economy of Gilbert Camp within the broader context of the Solomon Islands economy with a specific focus on the urban context.

\section{What is Sikret Fren? "Not really" morality}

At the beginning of this chapter, a sketch of the economic situation of Gilbert Camp was presented. Now, some further data are provided in order to complete this picture. First, it should be noted that Gilbert Camp residents normally do not own the land upon which they reside, nor have any right to use it. In those cases in which this constitutes a constant liability, the result is a recurrent drain of money. When settlers refuse to pay the landowner, their Temporary Occupation License, or a Fixed Term License, they might save some money, but live in a continual lack of security. Secondly, the cost of food is rather high. ${ }^{5}$ Exactly a month before my fieldwork began, the national newspaper Solomon Star published an article headed "Cost of living in Honiara, unbearable" (Kauhue, Solomon Star, 02/09/2011). In addition, as it was mentioned above, there is a general disproportion between the amount of money and the number of mouths to feed in the average Gilbert Camp household. Thirdly, school fees, transport, and consumables are very expensive too.

5. Just to give an idea of the shocks that affected the Consumer Price Index in the last decade, suffices to say that the price of rice was 2.5 times higher in 2011 than it was in 2002; the price of noodles doubled during the same time span. The cost of 500 gallons of water supply almost tripled, and that of 40 units of electricity was 5 times higher in 2011 than it was in 2002 (Solomon Islands National Statistics Office, Statistical Bulletin, 7/2011). 
In order to cope with the high costs of food, most residents cultivate their own horticultural garden. Those who own the house where they live tend to cultivate more often $(84 \%)$ than those who rent accommodation (63\%). That seems to suggest that in order to cultivate, residents prefer or need to be living in relatively stable conditions. Also, renters need to work to pay their rent, and might just not have enough time to cultivate. In both cases, vegetable production is not only used for home consumption, but also for sale. Those cultivators who turn into market sellers usually avoid intermediaries in order to secure higher returns (Kastom Gaden Association, 2005; Genova et al., 2010). However, since most settlers do cultivate a garden, the demand for horticultural products is limited. As a consequence, income-generating activities of other sorts are very common in Gilbert Camp.

Residents who can rely on a paid job and a piece of land to cultivate are relatively well off. In contrast, those who only have their job or their garden are ultimately dependent on the market for their subsistence. It is not surprising, therefore, that their entire lives pivot around the difficult task of generating an income, nor that this relatively small amount of money is entirely spent to survive.

However, the most hardworking among the residents manage to make a relatively considerable amount of money by simultaneously cultivating, working in town, and running a few income-generating activities. Clement, for example, works in the early morning as a pastor for one of the local SSEC churches, as a clerk in the afternoon, and in the evening he takes care of his poultry, piggery, and a small store he built in front of his house. All this, in addition to his garden. Tom, to take another example, regularly receives commissions from schools and churches to print labels on T-shirts. There are several printing services in town, but Tom's prices are extremely competitive: he does not pay taxes, nor does he pay collaborators. He does not spend much on materials either, as most of his tools are homemade. The final product might not be perfect, but it will do. Tom is also a teacher at the Naha Elementary School. He works from 9 a.m. to 5 p.m. He always gets the commission for the annual football tournament of the school, when more than $150 \mathrm{~T}$-shirts are needed. When he is not busy with his work and T-shirt prints, he takes care of a store that he built in front of his house, just like Clement.
The store, or maket haus, is probably the most common income-generating activity in Gilbert Camp. From the point of view of the settler, this is the easiest way to make a profit with relatively little labour. So easy, that stores have been mushrooming all over the place during the last decade. Along the 700 metres of a segment that runs on the main road between the top of the hill where Gilbert Camp begins and the old rain tree where it ends, I counted 25 maket haus. That means an average of one shop every 28 metres.

In sum, in order to confront their difficult economic conditions in the urban context, the people of Gilbert Camp work hard. And they believe that the members of each single household should find ways to produce their own food and money to make a living, without depending on other households. The mutual dependence between the members of the same household, however, connects each household with other households, because of the interactions of each individual with other householders that are outside of the supposedly autonomous household. And yet people would never say that their household is not autonomous. Indeed, no regular contributions come from other relatives or related households, nor are they expected. But some food and presents do sometimes enter the household as a consequence of connections with local churches, visiting relatives, and neighbours. These are essentially seen as occasional concretions of the value of relatedness, rather than regular assets. It follows that these contributions are not considered part of subsistence. Hence, it appears that, rather than a series of either autonomous or related households, each household is constantly negotiating a tension between the value of autonomy and the value of relatedness. ${ }^{6}$ These are the values according to which the Gilbert Camp residents are strongly motivated to live.

However, their efforts to advance economically while staying connected are situated within the general regressive tendency of the urban, regional, and national economy, which has not been growing despite all the natural resources with which Solomon Islands is endowed. The population, in contrast, has been growing with the second fastest growth rate in the Pacific $(2.7 \%$ in 2008 [Solomon Times Online, 2008], 2.59\% in $2011^{7}$ ). The country suffered a severe economic regression around 2000. In addition, the so-called 'Ethnic Tensions's between 1998 and 2003 and the subsequent civil unrest contributed to worsening the general economic situation. Between 1998 and 2002, the gross domestic pro-

6. This opposition between autonomy and relatedness resonates with Myers' ideas (1991: 22).

7. Population growth (annual \%) in Solomon Islands, World Bank.

8. The expression "Ethnic tensions" refers to the events that took place between 1998 and 2003 in Solomon Islands. Guadalcanese paramilitary groups like the Guadalcanal Revolutionary Army threatened the non-Guadalcanese settlers and about 20.000 of them escaped Guadalcanal (Dinnen, 2003; Carlin, 2004; Fraenkel, 2004). 
duct decreased by about $24 \%$. Thus, the population kept growing in a context of economic and political decline that resulted in raising commodity prices and the withdrawal of public services. Because of a general lack of investments and an increasing number of people placing further demand on already stretched services, Solomon Islanders live in a condition of worse general wellbeing compared to their Pacific neighbours. ${ }^{9}$ People in Gilbert Camp are strongly affected by this economic situation, if only because, living away from home on land they don't own, they heavily depend on commodities.

This quick sketch suggests that people in Gilbert Camp not only reside on the boundary that separates the town area from the customary land of Guadalcanal, they also live in a context characterised by the coexistence of commodity economy and Melanesian sociality. It is within the framework of this coexistence, I claim, that the survival strategies of the Gilbert Camp residents develop. To support this argument, I will now make a critical use of the categorical opposition between gifts and commodities. ${ }^{10} \mathrm{My}$ aim is to illustrate why Sikret Fren constitutes not only a survival strategy in the urban context, but also one possible solution to the incompatibilities between different regimes of value such as that of commodity economy and Melanesian exchange.

Gregory wrote that the social context of the exchange determines the motivation of transactors (Gregory, 1982: 100). Within a context of Melanesian gift exchange, the relationship between transactors is determined as one of rank difference. Exchange, as we have seen, results in a form of alternating domination that depends on a debt relation, although this is not universally observed in all Melanesian exchanges (Godelier, 1996). Debt is continuously reversed from one exchange partner to the other over a delayed period of time. Within the context of Sikret Fren, in contrast, a relation of rank difference is not established between two transactors. Rather, as mentioned above, it is one of equality between people and equivalence between things, just like in commodity exchange. Furthermore, the exchange of gifts does not result in mutual dependence, as is the case in classical Melanesian gift exchange. Indeed, even if the things exchanged during Sikret Fren were considered to be 'gifts' and described as inalienable from their donor, as a matter of fact the relationship between the exchange partners is one of mutual independence between aliens: they are not indebted, they do not know each other, and the two transactions (A->B and $\mathrm{B}->\mathrm{A})$ take place simultaneously. That is what the Mothers Union women meant when they said that ritual friends are "not really" friends: the qualitative relation between friends is fictive; it is actually a quantitative relation between things, i.e. the type of relation that pertains to the regime of commodity exchange. Lumped together, these features suggest that commodity exchange is the regime to which the ritual belongs.

However, it is not possible to situate Sikret Fren within that category of exchange. Indeed, it is ethnographically documented that people in Gilbert Camp do not see Sikret Fren as an exchange of commodities. Hence, this intersection of theoretical framework and ethnographic data shows that the objects exchanged are alienable, but "not really" alienable; that their relation is quantitative, but "not really" quantitative; that they establish independence between strangers but "not really" independence between strangers; lastly, that strangers are "not really" strangers. The ritual itself does not belong to a single category. It belongs at the same time to the category of gift exchange and to that of commodity exchange.

Those cups and plates are at the same time gifts and commodities. On the one hand, this is because they are a blend of what the analyst and the people see in them, i.e. at once gifts to ritual friends and marketable items purchased and exchanged in order to satisfy wants or needs. On the other hand, this is because they share at the same time features of both categories, for how Gregory has formulated them. Although, like commodities, Sikret Fren gifts are alienable, simultaneously exchanged between independent aliens, and equal in quantitative value, they do not spring from production and productive consumption; they cannot be explained in terms of control over productive labour; and, most importantly, the exchange is not intended to acquire the objects. So, if it is true that the motivation of transactors is determined by the social context of the exchange, then the social context of Sikret Fren is that of a gift society at the threshold of a commodity economy, which is exactly what Gilbert Camp is.

\section{Conclusion}

Establishing a relation between the type of exchange and the specific social context in which the exchange takes place brings us back to the

9. Australian Government Department of Foreign Affairs and Trade, 2004. "Solomon Islands: Rebuilding an Island Economy" (http://www.dfat.gov.au/publications/rebuilding_solomon/)

10. Gregory (1982) juxtaposed a specific Melanesian kind of exchange with a specific Western capitalist kind of commodity, but he also made it clear that in fact there are many hybrid forms. The distinction, therefore, is purely analytical and is used for analytical purposes. 
final question that this chapter posed: what is specific about Sikret Fren in relation to the general category of Melanesian like-for-like exchanges organised by Christian churches? Given the discussion above, it seems that the specificity of Sikret Fren lies in the rationale behind the organization of the ritual. The women of the Mothers Union organised it in order to cope with their need to buy useful goods and their commitment to honouring each other as valued members of a community. When these two priorities are not mutually compatible, that is the kind of dilemma that can be found on the threshold between a Melanesian settlement regulated by gift exchange and an urban context influenced by a regressive commodity economy. Since the ritual was organised in order to creatively cope with economic and moral values, the concept of moral economy can be helpful to illustrate how the women of the Mothers Union experienced such a challenge and how they addressed it. As mentioned in the first paragraph of this chapter, Thompson used the concept of moral economy to explain the English food riots. Rather than the economic impact of rising prices of grain and bread, he considered "the eighteenth-century English collier who claps his hand spasmodically upon his stomach" (Thompson, 1971: 78) as a reaction to the moral dimension of those material changes. Interestingly, Thompson challenged the economic understanding of food riots through reference to anthropological studies of exchange and moral obligation in Melanesia. It does not seem unreasonable, therefore, to use the concept of moral economy to understand the moral reaction to economic changes of a Melanesian people.

Thompson used ethnographies of Melanesia to argue that moral economy defines legitimacy and motivates political action. This concept can be applied to the network of the Mothers Union of Gilbert Camp, which I look at as a set of interconnected households. Thus, the adjective 'domestic' has to be added to the term 'moral economy'. This corresponds to taking the same direction that Peterson and Taylor took in their 2003 article. Indeed, Sikret Fren should be looked at from the same perspective that Nicolas Peterson took when he said:

"[Thompson] was working in a class society. I am working in a non-class society." (Nicolas Peterson, September 2012, personal communication)

Thus, in order to explore the impact of an increasingly monetised and commoditised economy on kin-oriented people, the moral economy of Gilbert Camp should be regarded from the point of view of the household, rather than that of political economy.

Thompson saw the market as becoming pervasive and destroying any morality, except for self- interest. In contrast, Gregory highlighted how the introduction of the market has not destroyed indigenous values. In some contexts, it has even provided the conditions for some of these values to flourish (Gregory, 1982). This historical phase surprised scholars who long believed money to be the destroyer of subsistence economies (Bohannan, 1959). The efflorescence in non-market monetary activities for the maintenance of kinrelations called for new ethnographic studies of this unexpected response to the penetration of market economy.

Values, far from being static, are the product of a changing socio-economic context that dynamically reflects the changing relationships between the 'valuers' who produce them, in a sort of dialectic relationship. Valuers can also find ways to harmonise local values with the values that rule the market. Ritual activities constitute a site of negotiation in which such transformation often takes place. Sikret Fren is an example of how people in Solomon Islands creatively cope with the multiple liabilities that result from their moral commitment to their community and their need to make ends meet. They do so by constructing cups and plates as conceptual objects, as giftcommodity hybrids, at the same time secret and "not really" secret, exchanged between randomly-selected partners who look at each other as 'friends', but are 'not really' 'friends'. In this way, their domestic moral economy defines the limits of what is acceptable, necessary, and legitimate, and motivates ritual action.

My understanding of the "social construction of objects" does not imply that all objects shall be considered as social constructions (Goodman, 1978), nor that the qualities of these objects are stable and objective (Appadurai, 2011). Furthermore, I do not think that the social construction of things is necessarily intentional. However, a group of people with certain values and needs can act intentionally, and construct an object as a result. In socially constructing the hybrid objects for their exchange, the women of the Mothers Union created an alternative space to their reality. But, alternative to what?

One possibility is that the objects involved in this ritual are actually more gifts than they are commodities, thereby creating a space of exchange that is alternative to the market. As such, however, they are also distanced from traditional forms of Melanesian gift in order to make a specifically Christian point about the equality of sisterhood. This kind of exchange (non-competitive, simultaneous, and exactly balanced) can be interpreted as a kind of rejection of $\mathrm{Me}-$ lanesian exchange logic. Altering the logic of gift exchange in this way implies a critique of the indigenous idea of the gift that establishes a temporary inequality and is used for personal renown. In distancing themselves from this form 
of gift, people constitute themselves not only as independent from market logics, but also as part of a 'Christian' community governed by an undifferentiated benevolence, as opposed to an alternating domination. Within such a community, it does not matter who your relative is. The women of the Mothers Union are all sisters in God and help each other out accordingly. Hence, the importance of equality, and the irrelevance of actual kinship ties in Sikret Fren ensues. ${ }^{11}$

A second interpretive direction, which does not exclude the first one though, is that this ritual represents the particular cultural outcome of a specific socio-economic situation. This possibility consists of the idea that the logic that underpins Sikret Fren, i.e. cultural creativity, could be abstracted as if it constituted the general principle of negotiation of moral economy in Gilbert Camp. In this chapter, I argued that Sikret Fren is one way in which people in Gilbert Camp create concrete spaces of negotiation between the economic costs of a commodity economy and the moral values of a gift society. Without implying that some economies are moral and others are not, I tried to show that there is a clear relation between Gilbert Camp as a historically and geographically specific socio-economic context and the cultural response its people elaborate in order to cope with the conflicting priorities that are themselves specific of that particular context. The next step of this reasoning would be to explore the possibility, hinted at above, that such cultural response could be considered to be a general attitude of people who find themselves coping with dilemmas emerging from incompatibilities between urban and rural context.

True, the cultural creativity of people confronted with the diffusion of monetised and commoditised economy has been already documented. However, as the logic of the market continues to propagate, rituals of this kind remind us that human creativity also continues to respond to these historical changes and challenges; and that it does so with an efflorescence of different moral economies, an image that strikingly contrasts with that of a homogenous world, regulated by the mere allocation of scarce resources to alternative ends.

\section{Acknowledgements}

I wish to acknowledge the helpful advice provided by Chris Gregory and Karen Sykes, particularly concerning the ethnographic literature on like-for-like gifts in Melanesia. In addi- tion, I wish to thank Peter Wade for his kind advice on ways to push my argument further, and Gillian Evans for suggesting me to better contextualize my case study within the broader economic situation in Solomon Islands. My special thanks are extended to my colleagues from the Department of Social Anthropology at the University of Manchester for their generous feedback on earlier versions of this paper. I wish to acknowledge the generous feedback I received during the workshop entitled "The Costs of Culture: Ritual Economics and the Domestic Moral Economy", Queen's University, Belfast, on 16-17 September 2013, particularly by Jonathan Parry. My research has been possible thanks to the funding associated to the ESRC project "The Domestic Moral Economy: An Ethnographic Study of Value in the Asia-Pacific Region." Lastly, I thank the Royal Anthropological Institute for awarding the Arthur Maurice Hocart Prize to an earlier version of this chapter.

\section{REFERENCES}

Appadurai Arjun, 1988. The Social Life of Things: Commodities in Cultural Perspective, Cambridge, Cambridge University Press.

Bell Andrew, 1807. Extract of a Sermon on the Education of the Poor Under an Appropriate System, London, T. Bensley.

BuIzard William, 1796. Suggestions for the Improvement of Hospitals, and Other Charitable Institutions, London, HL Galabin.

Bohannan Paul, 1959. The Impact of Money on an African Subsistence Economy, s.l., Bobbs-Merrill.

Carlin Jocelyn, 2004. The Day Peace Died, Inside Out 38.

Dinnen Sinclair, 2003. Violence in Melanesia: Overview and Interpretation, PazifikInformationsstelle (Hrsg.): Gewalt Im Pazifik 65, pp. 4-9.

Dundon Alison, 2011. Negotiating the Horizon - Living Christianity in Melanesia, The Asia Pacific Journal of Anthropology 12 (1), pp. 1-12.

Forge Anthony, 1972. The Golden Fleece, Man 7 (4), pp. 527-540.

-, 2004. Marriage and Exchange in the Sepik, in R. Needham (ed.), Rethinking Kinship and Marriage, London, Routledge.

11. This interpretive direction was kindly suggested to me by Jonathan Parry during the workshop entitled "The Costs of Culture: Ritual Economics and the Domestic Moral Economy", convened by Fiona Magowan and Karen Sykes. Queen's University, Belfast, on 16-17 September 2013. 
Fraenkel Jon, 2004. The Manipulation of Custom: from Uprising to Intervention in the Solomon Islands, Canberra, Pandanus Books.

Genova Christian, S. Kathrin Kriesemer, Suzanne Neave, Jaw-Fen Wang and Katinka Weinberger, 2010. Market Analysis of Fresh Vegetables in Solomon Islands, Shanhua, Taiwan, AVRDC-World Vegetable Centre.

Godelier Maurice, 1996. L'énigme du don, Paris, Fayard.

Goodman Nelson, 1978. Ways of Worldmaking, Indianapolis, Hackett Publishing.

Gregory Chris A., 1980. Gifts to Men and Gifts to God: Gift Exchange and Capital Accumulation in Contemporary Papua, Man 15 (4), pp. 626-652.

Gregory Chris A., 1982. Gifts and Commodities, London/New York, Academic Press.

Kauhue E., 2011 (02/09/). Cost of living in Honiara, unbearable, Solomon Star.

Kastom Gaden Association, 2005. People on the Edge, Honiara, Solomon Islands, Kastom Gaden Association.

Maggio Rodolfo, 2014. The anthropology of storytelling and the storytelling of anthropology, Journal of Comparative Research in Anthropology and Sociology 5 (2), pp. 89-106.

Maggio Rodolfo and Jessica Symons, 2014. Journal of Comparative Research in Anthropology and Sociology 5 (2), pp. 1-6.

Malinowski Bronislaw, 1922. Argonauts of the Western Pacific: An Account of Native En- terprise and Adventure in the Archipelagoes of Melanesian New Guinea, London, Routledge.

Myers Fred R., 1991. Pintupi Country, Pintupi Self: Sentiment, Place, and Politics Among Western Desert Aborigines, Berkeley and Los Angeles, University of California Press.

Peterson Nicolas and John Taylor, 2003. The Modernising of the Indigenous Domestic Moral Economy, The Asia Pacific Journal of Anthropology 4 (1-2), pp. 105-122.

Sahlins Marshall, 1972. Stone Age Economics, New Brunswick, New Jersey, Transaction Publishers.

Scotт James C., 1977. The Moral Economy of the Peasant: Rebellion and Subsistence in Southeast Asia, New Haven, London, Yale University Press.

Skoda Uwe, 2004. Ritual Friendship in a Converging Tribal and Caste Society, Journal of Social Sciences 8 (2), pp. 167-77.

SOLOMON TIMES ONLINE, 2008 (05/06). Solomons Population, Second Fastest Growth Rate in Pacific (http://www.solomontimes. com/news/solomons-population-second-fastest-growth-rate-in-pacific/1896).

Strathern Andrew, 1971. The Rope of Moka: Big-men and Ceremonial Exchange in Mount Hagen, New Guinea, Cambridge, University Press, Cup Archive.

Thompson Edward P., 1971. The Moral Economy of the English Crowd in the Eighteenth Century, Past \& Present 50, pp. 76-136.

White Geoffrey M., 1991. Identity Through History: Living Stories in a Solomon Islands Society, Cambridge, Cambridge University Press. 